\title{
Geoelectric studies of the Kozloduy nuclear power plant region, Bulgaria
}

\author{
I. Logvinov' ${ }^{1}$, G. Boyadzhiev ${ }^{2}$, B. Srebrov $^{2}$, L. Rakhlin ${ }^{3}$, G. Logvinova ${ }^{1}$, \\ S. Timoshin ${ }^{3}, 2021$
}

${ }^{1}$ S.I. Subbotin Institute of Geophysics of the National Academy of Sciences of Ukraine, Kyiv, Ukraine

${ }^{2}$ Institute of Mathematics and Informatics of the Bulgarian Academy of Sciences, Sofia, Bulgaria

${ }^{3}$ Research Centre GEOMAGNET, Lviv, Ukraine

Received 1 September 2021

\begin{abstract}
The task of the work was geoelectrical studies using variations of the magnetotelluric (MT) field of the Kozloduy nuclear power plant (KNPP) region and the integration of its results with other geological and geophysical knowledge. This paper presents the determined interpretation parameters of the MT field. The KNPP is located on the right bank of the Danube River in close proximity to the river. This fact, together with the location of electrified railways determined the unique network of locations of observation points for MT field variations. Based on the analysis of Earthquake Catalogs of Bulgaria and international seismicity databases, a map of the seismicity of nuclear power plant areas was built. Over the past 50 years, about 750 earthquakes (mainly south of KNPP) have been recorded at a distance of $40-80 \mathrm{~km}$ from the KNPP. Two magnetotelluric stations GEOMAG-02 were used at measurement sites, but equipment for recording electrical channels was available only for one station (due to the lack of another set of non-polarizable electrodes). The MT field variations were observed at 21 points, which are located on the territory with sides approximately $30-35 \mathrm{~km}$ from east to west and $40-50 \mathrm{~km}$ from north to south. For all observation points on the profile, only the parameters of the vertical magnetic transfer function (VMPF) were determined, in the form of the real $\left(C_{u}\right)$ and imaginary $\left(C_{v}\right)$ parts of the induction vector. The steadily induction vector was defined for periods from $10-20$ to $4900-10800 \mathrm{~s}$. For most points it was possible to estimate the values $C_{u}, C_{v}$ with an error of $0.02-0.04$ and $\mathrm{Az} C_{u}, \mathrm{Az}_{v} 3-5^{\circ}$. The analysis showed the presence of anomalous behavior of $C_{u}, C_{v}$ in different intervals of periods at some points. In the shortest (about $20 \mathrm{~s}$ ) and longest periods ( 600 to $1000 \mathrm{~s}$ ), the $C_{u}$ directions completely coincide and indicate the presence of anomalous conductivity of the quasi-longitudinal strike to the west of the study area. This behavior of the $C_{u}$ vector is in good agreement with power isohypsum strike of the Cenozoic deposits. At intermediate periods of $50-200 \mathrm{~s}$, the behavior of $C_{u}$ is more complex. Approaching the zone of high seismicity, the direction of the $C_{u}$ differs from the previous ones by almost $90^{\circ}$. On the Geoelectrical sections, obtained as a result of 1D inversions of MTS curves at 4 points located in the southern part of the region, anomalous layers are identified ( $\rho$ about $10 \mathrm{ohm} \cdot \mathrm{m}$, the depth of the center of the object is 15-20 km). It can be assumed that well-conducting objects in the Earth's crust of the region, apparently, prevent the propagation of seismic waves from nearby earthquakes to the north towards the KNPP.
\end{abstract}

Key words: conductivity, seismicity, nuclear power plants of Bulgaria.

Introduction. Geoelectrical studies play a significant role in the construction of complex geophysical models of deep crustal structu- res, which contribute to solving the problem of predicting catastrophic natural disasters [ Srebrov et al., 2018; Logvinov et al., 2020 
and other]. The integration of the results of magnetotelluric (MT) and other geophysical methods makes it possible to obtain additional information revealing the internal structure and history of the formation of geological structures.

Earthquakes are one of the most disastrous natural phenomena, the impact of which must be taken into account in the operation of nuclear power plants. Based on this, in order to establish the parameters of the real seismic hazard in the areas where nuclear power plants (NPPs) are located, it is important to have a set of geophysical data that will make it possible to clarify the geotectonic situation around the NPP. Over the past 50 years, more than 10000 earthquakes have been recorded in Bulgaria. Seismic events were documented within the Maritsa zone as well as the Moe/ ian Platform. In the Kozloduy nuclear power plant (KNPP) region about 750 events have been documented.

Therefore, the main task of this work was the geoelectric study using variations in the magnetotelluric (MT) field in the KNPP region and their comparison with other geological and geophysical knowledge. This approach allows us to expand our knowledge of the deep structure of the KNPP region. The network of observations of various geophysical methods allows using them to create maps of detailed and general seismic zonation. The KNPP (Fig. 1) is located on the right bank of the Danube River in close proximity to the river (see Fig. $3, b$ ). This fact determined the uniqueness of the choice of the network for

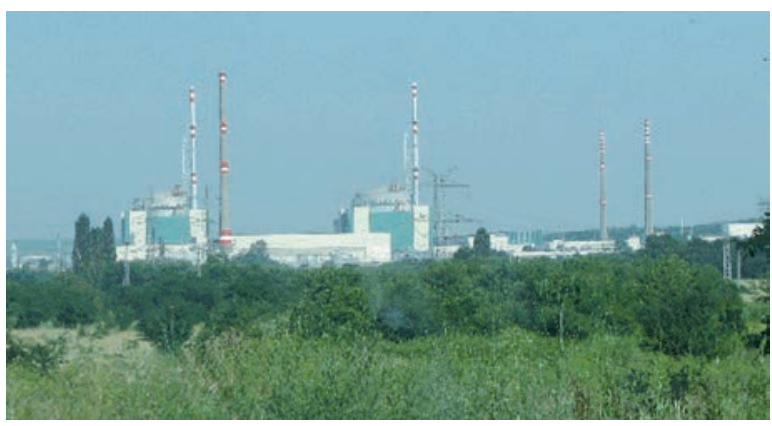

Fig. 1. Kozloduy nuclear power plant. the location of observation points. This fact determined the uniqueness of the network of locations of observation points for MT field variations.

Experimental investigation and processing of records of variations of MT field components. Registration of MT field components. Noise characterization is important when recording signals with frequencies of less than $1 \mathrm{~Hz}$. The geoelectrical measurements were carried out using the GEOMAG2 fluxgate magnetometers [Dobrodnyak et al., 2014] which registers variations in the MT field components with a high sensitivity threshold. Optimization of the excitation mode of the sensor by increasing its excitation field greatly improved the noise characteristics of the GEOMAG-02. The following requirements for the noise characteristics of the GEOMAG-02 in the frequency range of $\mathrm{DC}$ to $0.2 \mathrm{Bz}$ are set as per the recommendations made by the INTERMAGNET definitive 1 s data standard [Turbitt et al., 2012]: noise level in the frequency band DC is set to $8 \mathrm{mHz}$ less than 100 pT RMS (root mean square) and noise level in the frequency band $8 \mathrm{mHz}$ is set to $0.2 \mathrm{~Hz}$ less than $10 \mathrm{pT} / \sqrt{\mathrm{Hz}}$ at $0.1 \mathrm{~Hz}$. Fig. $2, a$ represents the basic frequency-noise response of the GEOMAG-02 under controlled conditions at manufacturing location (Lviv, Ukraine), with a noise density of $10 \mathrm{pT} / \sqrt{ } \mathrm{Hz}$ at $0.1 \mathrm{~Hz}$. Fig. 2, $b$ shows graph of noise density in the frequency range from $8 \mathrm{mHz}$ to $0.2 \mathrm{~Hz}$ as a result of the low-frequency digital filtering at a cut off-frequency of $0.2 \mathrm{~Hz}$, with window width being $25 \mathrm{~s}$. Experimentally obtained graphs confirm the achievement of the necessary noise characteristics (as is shown in Fig. 2). The data format corresponds to the Recommended Standard: text line format, sensitivity threshold $1 \mathrm{pT}$ and time-stamp accuracy (centered on the UT second) better than $0.01 \mathrm{~s}$.

As follows from the description of the technical characteristics, the equipment fully meets the necessary requirements for the planned research.

During the experimental work in 2021, two magnetotelluric stations GEOMAG-02 were used at measurement sites. One station is 


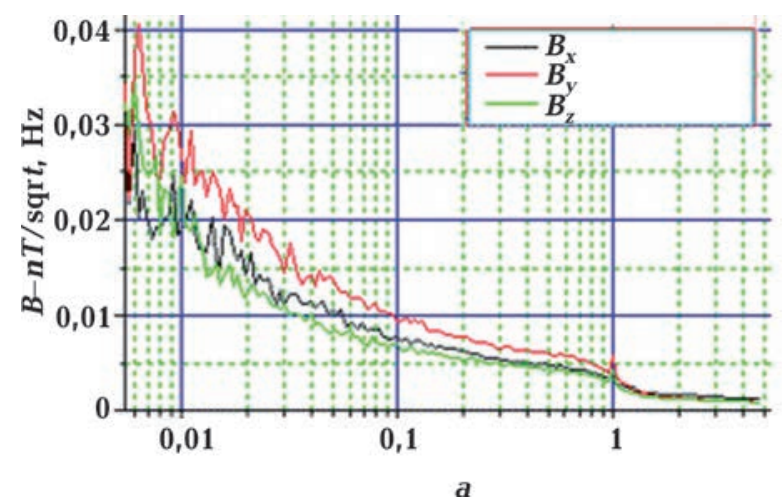

a

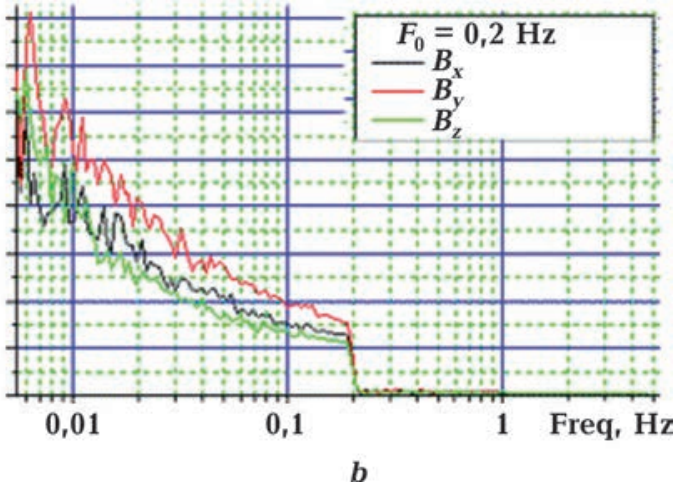

b

Fig. 2. Noise characteristics of different magnetic components of GEOMAG-02 (a); noise characteristics as a result of digital filtering at $F_{0}=0.2 \mathrm{~Hz}(b)$.

the property of the Institute of Mathematics and Informatics of the Bulgarian Academy of Sciences; the second belongs to the Institute of Geophysics of the National Academy of Sciences of Ukraine.

Observation network selection. The useful signal is registered together with the interference. By nature, the sources of interference are divided into model, industrial, instrumental, measuring.

Model interferences are created by the nonlinear part of the MT field, which is associated with the characteristics of MT field sources that do not correspond to the accepted theoretical positions (pulsations in the zones of auroras and multitudes of resonant field maxima, near thunderstorms, etc.). The influence of these reasons extends over distances of hundreds of kilometers. All other things being equal, the level of the indicated interference increases in areas of high resistance of surface rocks and attenuates in low-resistance ones.

Industrial disturbances are associated with stray currents from of electrified railways, pipelines, power lines, telegraph lines, radio stations and radar installations. They are local in nature. According to theoretical and experimental data, their radius does not exceed $10-20 \mathrm{~km}$ and depends on the electrical resistance of surface deposits. Interference can be stationary with a fundamental frequency of $50 \mathrm{~Hz}$ and non-stationary with a wide frequency spectrum. High-impedance blocks of the Earth's crust are excellent waveguides for industrial disturbances, therefore, within their limits the disturbances extend for much greater distances than within low-impedance blocks.

Industrial barriers are a serious obstacle to MTS. Particular difficulties arose in conducting soundings near cities with well-developed industry. Large industrial centers are usually interconnected by electrified railways, highpower power lines, cable and wired communication lines. The data already obtained demonstrate serious distortions of MT fields and interpretation parameters caused by industrial sources, including the effects of electrified railways, pipelines and industrial plants.

Electrified railways and pipelines generate electromagnetic interference in a wide range of frequencies. Whenever possible, MTS points should be located as far as possible from sources of industrial interference. Interference with a frequency of $50 \mathrm{~Hz}$ was suppressed by notch filters included in each channel of the GEOMAG-02 equipment.

Therefore, first of all, it was necessary to assess the presence of these sources of interference.

Fig. 3, a shows the position of the KNPP and electrified railways in the study region. Typically, interference from these sources has a significant impact on distances up to 20-25 $\mathrm{km}$. Very strong interference was registered in the records of variations of electrical components at the first point (Mot), located $10 \mathrm{~km}$ from the KNPP. Interference on the magnetic 


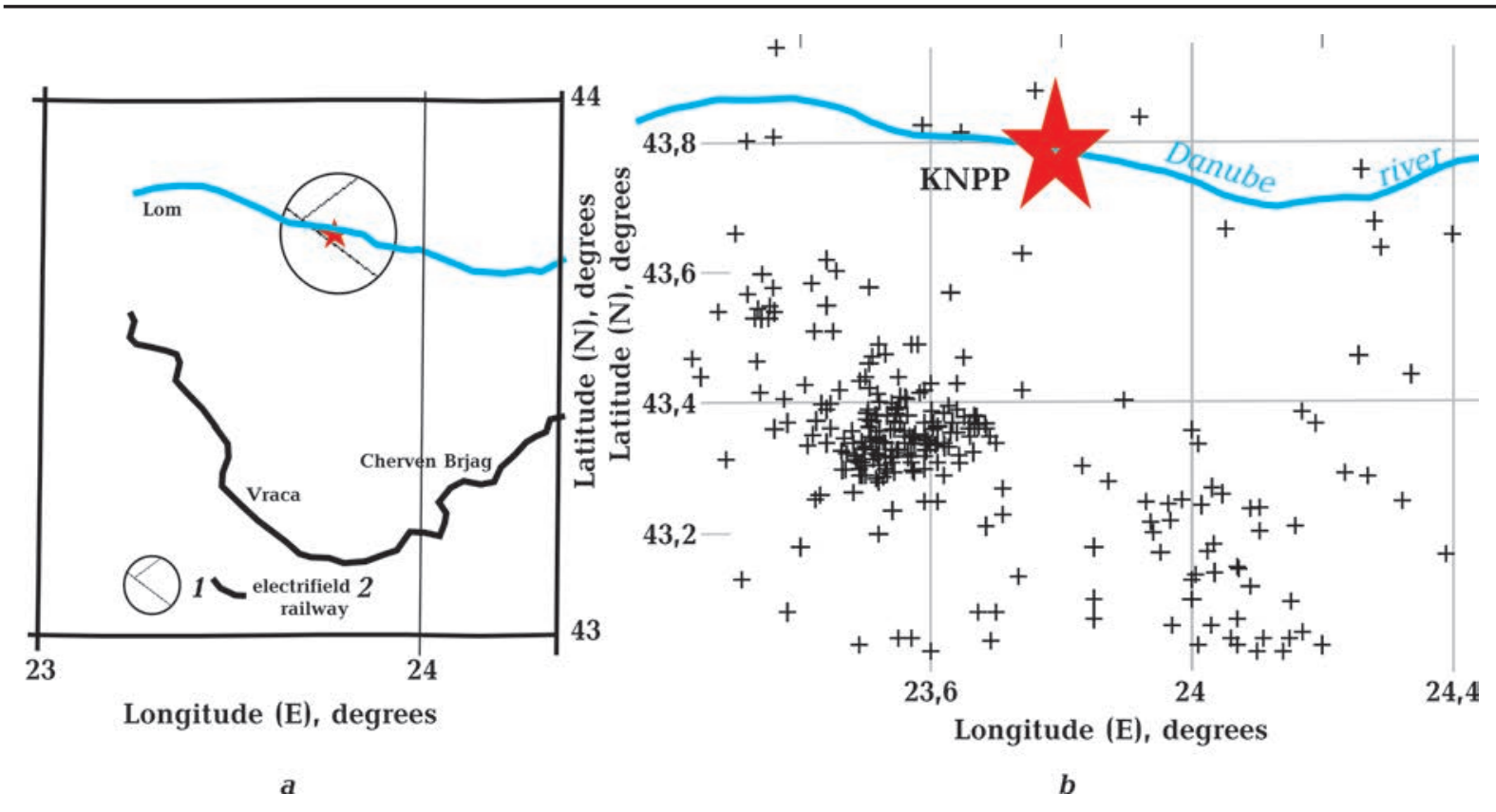

Fig. 3. Sources of interference on the electrical components of the MT field (a): 1 - Kozloduy nuclear power plant (red star) and its probable zone of influence on the electrical components of the MT field, 2electrified railway (https://www.bdz.bg). Distribution of earthquake epicenters during 1973-2020 (b).

components of the MT field decreases in proportion to the cube of the distance from the interference source. Taking into account the above, it was decided to register the magnetic components at the closest possible distance from the KNPP. Five components were recorded at four points at a distance of more than $25 \mathrm{~km}$ from the KNPP (one of the points $15 \mathrm{~km}$ from the electric railway). The presence of electrified railways automatically limited the area of experimental research from the west and south the west and south.

Instrumental interferences include GEOMAG-02 equipment noise: intrinsic noise and drift of amplifiers and sensors, leaks in equipment and measuring lines, electrochemical processes at non-polarized electrodes. This type of interference is easily recognized and observed by GEOMAG-02 operators visually.

Another important factor determining the choice of the research area is the seismicity of the NPP region. Fig. $3, b$ shows the distribution of the epicenters of the earthquakes closest to the NPP with a magnitude of more than 2 (http://crustal.usgs.gov/geophysics/ index.htm; http://www.isc.ac.uk/iscbulletin/ search/catalogue/; http://www.emsc-csem. org/Earthquake; http://service.iris.edu/irisws/ fedcatalog/1/; https://earthquake.usgs.gov/ earthquakes/search/; https://doi.org/10.7914/ SN/BS). Based on the above data, the research area in the west and south was limited by the zone of influence of electrified railways.

The aim of the study was to determine possible conductivity anomalies in the KNPP region. The distance between observation points was $10-15 \mathrm{~km}$. According to previous MT studies [Srebrov et al., 2018] in the immediate vicinity of the KNPP, conductivity anomalies are observed in the range of periods of $10-1000 \mathrm{~s}$.

The cars used in the expedition were not adapted to dirt roads, which made it difficult to select the sites for observation points. This fact and the high density of agricultural crops posed serious challenges for the operators, particularly when infrastructural and environmental conditions were far from ideal and did not allow making a given density of observations and in many cases prevented the installation of lines to record the electrical components of the MT field. 
Observations of the MT field were made at 21 points (Fig. 4) which cover an area of $30-35 \mathrm{~km}$ in longitude and $40-50 \mathrm{~km}$ in the latitudinal direction. Due to the inexperience of the observers and technical malfunctions at several points, the MT field variations were recorded over a shortened recording period. This determined the quality of the obtained interpretation parameters. As follows from Fig. 4 , the location of the MT observation points makes it possible to analyze the influence of the seismicity of the Kozloduy region on the interpretation parameters.

Processing records of $M T$ field variations. The analysis of the obtained records of MT field variations indicates that industrial and domestic interference can be superimposed on the measurements. The basis of primary processing is smoothing (filtering) records of MT field variations in order to filter out random outliers. In practice, data cleansing is time-consuming and often done manually. It is rather difficult to create a universal program for "cleaning" various noises by filtering methods, since with noises there is always a possibility of removing useful signals. As a result, recordings can be significantly distorted and not correspond to natural processes. In some cases, records are discarded as low-quality.

In the world practice of processing MT field variations, each author uses different approaches to solving this problem. Often,

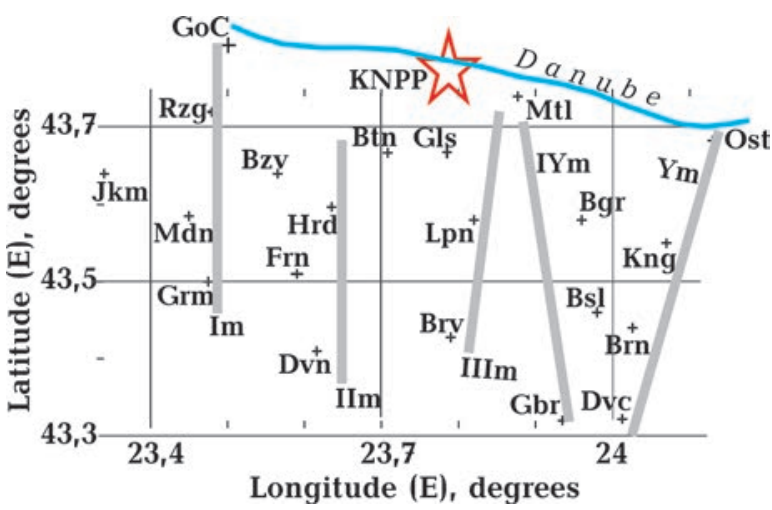

Fig. 4. Location of the observation sites (cross) and meridional profiles (grey lines) along which observation points are grouped. areas of a record with a strong background of interference are simply "gouged out» when processing the data.

It is convenient to carry out digital signal processing using the MATLAB software. The built-in programming language makes it easy to create algorithms. Numerous functions of MATLAB and Toolbox greatly simplify programming. Users of ready-made programs, even without knowledge of the software, can start processing and visualizing data almost immediately. It is enough to enter the name of the $\mathrm{M}$ file without the extension in the command line.

To perform primary processing at the Institute of Geophysics of the National Academy of Sciences of Ukraine, a number of programs (GIS TARIG system) were written that allowed us quickly eliminate intermittent interference. In years of quiet solar activity, daily records are characterized by a smooth change in MT field variations. Dst variations are extremely rare, which makes it possible to use a simple algorithm for recovering records taking into account the difference in values between adjacent points. The GIS TARIG system offers a set of programs (SKACHOK) for "cleaning» MT field variation records for GEOMAG stations, allow quickly (especially in comparison with manual "cleaning») eliminat interference in all components at the same time. The cleaning programs are used in stages, depending on the type of interference. During the execution of the first stage of the SKACHOK program, recording trends are eliminated for each component separately; if necessary, the recording of MT field variations can be decimated. Finally, the MT field components are recalculated to the zero level. The original and corrected data are displayed on Fig. 5.

All data processing was carried out using two programs [Varentsov, 2007] and [Ladanivskyy, 2003]. Stage 1 of the experimental data ended with estimates of impedance (Z) and vertical magnetic transfer function (VMPF) within the framework of a single-point processing scheme.

Estimates of interpretation parameters (impedance and VMPF parameters). The main provisions of the theory of MT research 

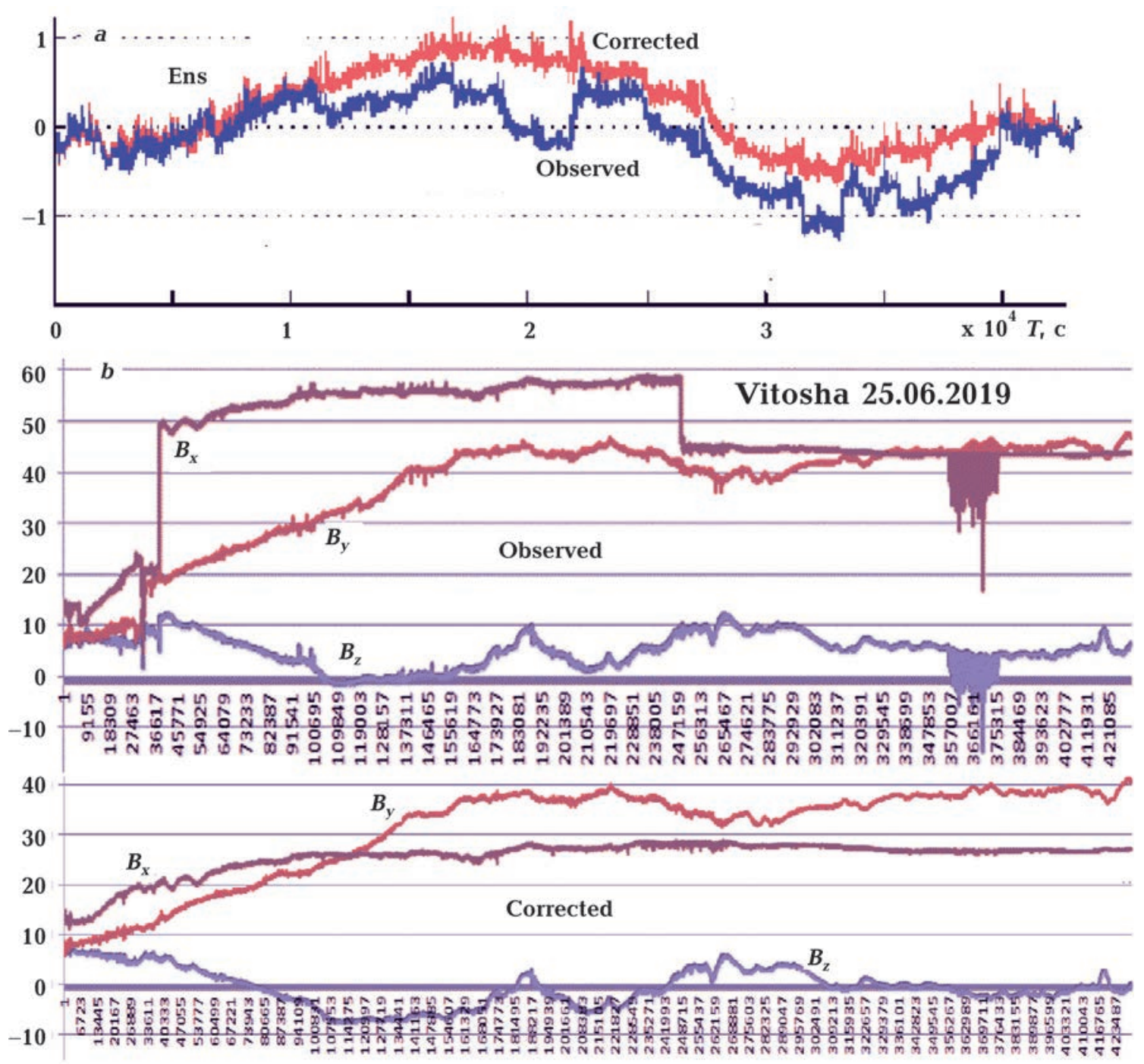

Fig. 5. An example of using the first stage of the SKACHOK program, as a result, the rough jumplike upshoots observed during registration of MT field variations have been corrected: electrical Ens (northern) and magnetic $B_{z}$ (vertical), $B_{x}$ (northern), $B_{y}$ (eastern) component are eliminated.

are set out in the work [Berdichevsky, Dmitriev, 2008]. Geoelectrical methods using variations of the magnetotelluric field are based on the representation of an external source of the MT field as a plane wave incident on a horizontally layered Earth. For this type of representation, the vertical magnetic component is zero at the Earth's surface. Depending on the components of the MT field used, the results are presented in the form of magnetotelluric (MTS) and magnetovariational (MVS) soundings (table).

The main interpretation parameter of the MTS method is the impedance, which is de- termined from the ratio of the electric and magnetic components of the MT field. The impedance depends on $\rho$ of the medium and therefore, by measuring it at different periods and using the phenomenon of the skin effect, it can be used to determine the electrical resistance of the medium at different depths.

Table shows the values of the skin layer (i.e., the order of depths) that can be studied by magnetotelluric methods, depending on the used period of variations. These data make it possible to correctly estimate the power of the model for real values to interpret the MT field variation periods. 
Skin depth $(\mathrm{km})$ for different values of resistivity $(\rho)$ and periods of MT field variations [Akasofu, Chapman, 1973]

\begin{tabular}{|c|c|c|c|c|}
\hline \multirow{2}{*}{$\rho, \mathrm{ohm} \cdot \mathrm{m}$} & \multicolumn{4}{|c|}{ The period of variation of the MT field, $\mathrm{s}$} \\
\cline { 2 - 5 } & 0.1 & 10 & $10^{3}$ & $10^{5}$ \\
\hline $10^{4}$ & 16 & 160 & 1000 & \\
$10^{3}$ & 5.0 & 50 & 300 & 5000 \\
$10^{2}$ & 1.6 & 16 & 100 & 1600 \\
$10^{1}$ & 0.50 & 5.0 & 30 & 500 \\
$10^{0}$ & 0.16 & 1.6 & 16 & 160 \\
\hline
\end{tabular}

When analyzing MTS data, the values of apparent resistivity $\left(\rho_{\mathrm{k}}\right)$ are used as the final result of processing the original records of variations in the MT field. Usually, the values $\rho_{\mathrm{k}}$ are used for subsequent estimates of the Geoelectrical parameters of the Earth's interior.

The MVS method uses interpretation parameters (magnetic transfer functions) obtained from measurements of the magnetic components of the MT field. The results of processing from one station are usually based on the relationship (called the Wise-Parkinson relationship) between vertical component $\left(B_{z}\right)$ and its horizontal $\left(B_{x}-\right.$ northern and $B_{y}-$ eastern) magnetic components of the MT field $B_{z}=W_{z x} B_{x}+W_{z y} B_{y}$, where $W_{z x}, W_{z y}$ - vertical magnetic transfer function (VMPF).

Transfer functions are usually presented in the form $C_{u}=\operatorname{Re} W_{z x}(\omega, r)+\operatorname{Re} W_{z y}(\omega, r), C_{v}=$ $=\operatorname{Im} W_{z x}(\omega, r)+\operatorname{Im} W_{z y}(\omega, r)$, where $C_{u}$ is the real and $C_{v}$ is the imaginary part of $W(\omega, r)$ [Schmucker, 1970].

On the map, $C_{u}$ and $C_{v}$ can be presented in the form of induction arrows (positive values of the azimuth of the arrow are plotted clockwise from the north direction). By the ratio of $C_{u}$ and $C_{v}$, a number of important conclusions can be drawn about the geoelectric structure in the vicinity of the observation point.

Between conducting objects and the geometric parameters of anomalies of magnetovariational parameters, there are relationships determined by the Biot-Savart law. Above the middle part of the conductor elongated along the $x$-axis, the modulus of the induction arrow is close to zero and has extrema to the left and right of the projection of the edges of the conducting object onto the Earth's surface. The distance between the extrema increases with the depth of the conductor. $C_{u}$ changes sign and a minimum on the left and a maximum on the right relative to the middle of the conductor. Therefore, with a close, laterally or vertically, location of the conductors in connection with the superposition of the field, the above relations for the induction arrow can vary greatly.

VMPF parameters. For all observation points indicated above, only VMPF parameters (in the form of real $\left(C_{u}\right)$ and imaginary $\left(C_{v}\right)$ parts of the induction vector) were determined on the profile. The steadily induction vector has been defined for periods from $10-20$ to $4900-10800 \mathrm{~s}$. At large periods, the amplitude estimates of the induction vector are unstable or absent either due to insufficient time of registration of variations, or due to the large contribution of the field of an external source of variations.

For the convenience of the preliminary analysis of the obtained values of the VMPF parameters, the observation points were grouped according to the meridional (Im-Ym) profiles (see Fig. 4). Fig. 5 shows the resulting frequency curves of the amplitudes (lengths) and azimuths of the $C_{u}$ and $C_{v}$. In most points it was possible to estimate the values $C_{u} C_{v}$ with 
an error of $0.02-0.04$ and $\mathrm{Az} C_{u}, \mathrm{Az}_{v} 3-5^{\circ}$. which anomalous behavior of the parameters

On the prIm (Fig. 6, a) in all sites, two in- of the induction vector is observed. The first tervals of periods can be distinguished, at interval is in all site at periods less than $100 \mathrm{~s}$.
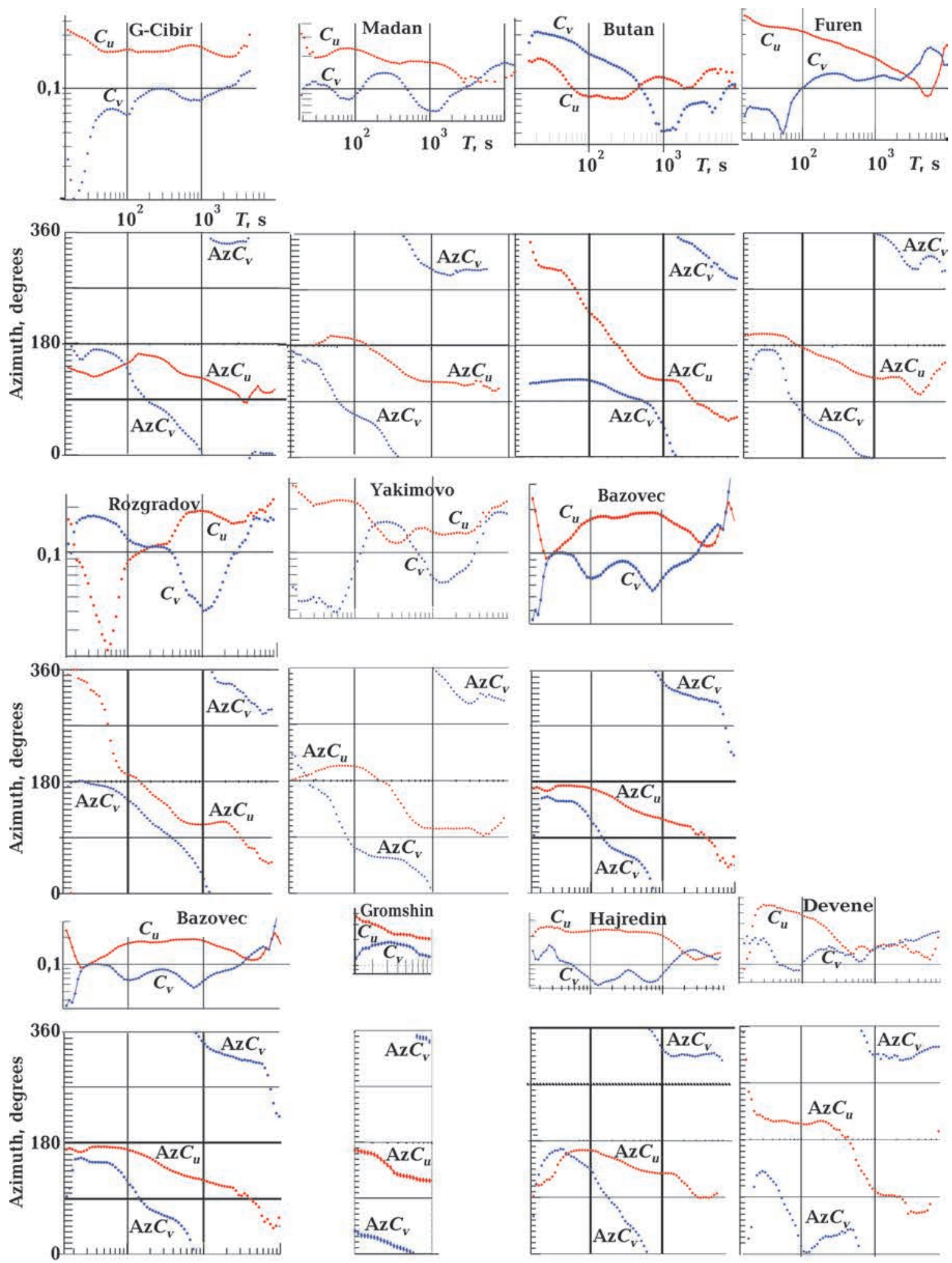
The ratio of $C_{u}$ and $C_{v}$ corresponds to a two- values of $C_{v}$ of the order of 0.01 . Az $C_{u}$ varies dimensional conductivity anomaly - the from $130-140^{\circ}$ in $\mathrm{GCb}$ to $170^{\circ}$ in $B_{z v}$. At the maximum $C_{u}$ corresponds to a minimum $C_{v}$. rest of the points of the profile, the maximum At $\mathrm{GCb}$ and $B_{z v}$ at periods of about $20 \mathrm{~s}$, the of $C_{u}$ falls on the interval of periods of $50-90^{\circ}$. maximum $C_{u}(0.2-0.3)$ corresponds to the The maximum period for $C_{r}$ increases from

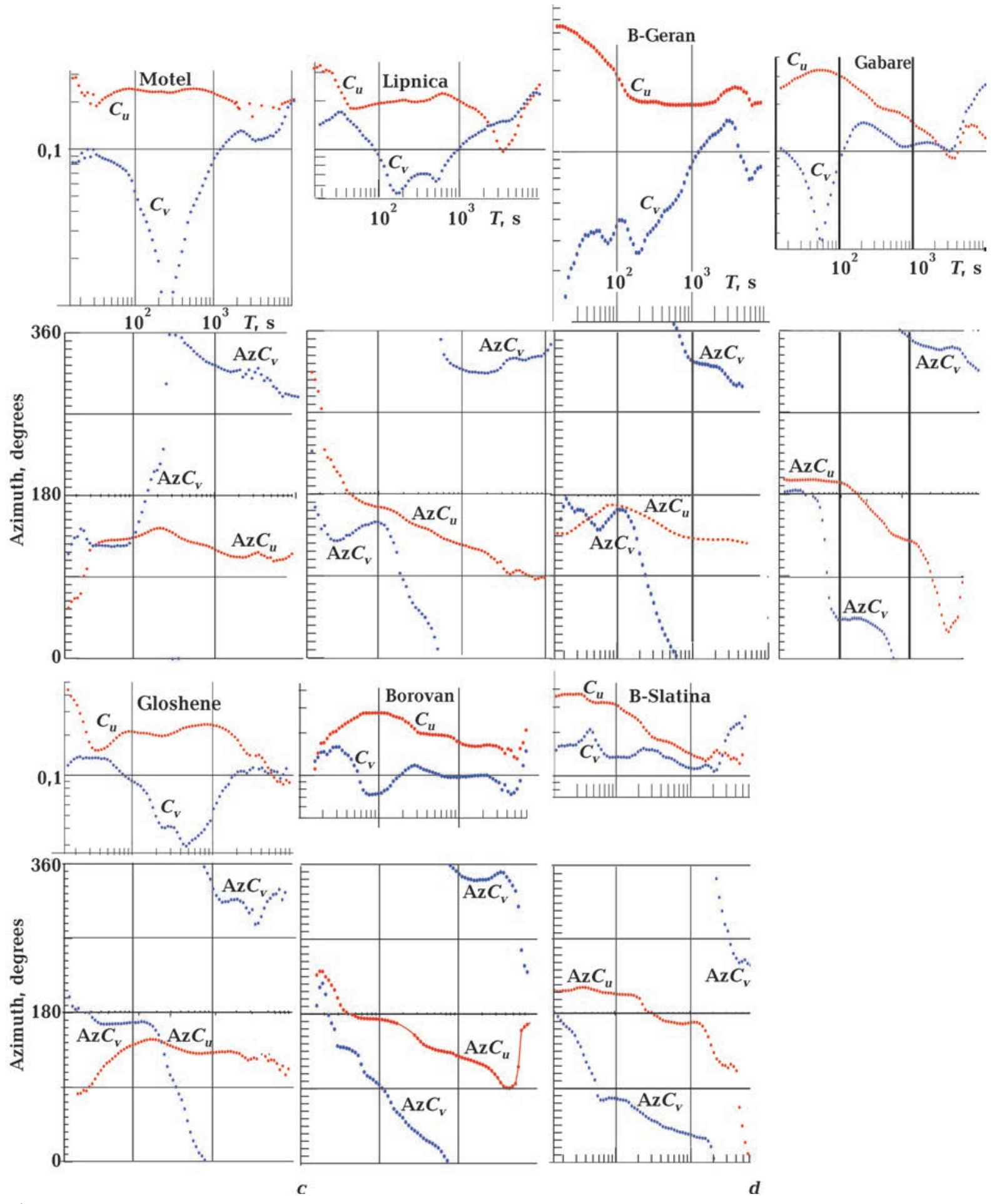

Fig. 6. Frequency curves $C_{u}, C_{v}$ and $\mathrm{Az} C_{u}, \operatorname{Az} C_{v}$ along: prim $(a), \operatorname{prIIm}(b), \operatorname{prIIIm}(c), \operatorname{prYm}(d), \operatorname{prYm}(e)$ 

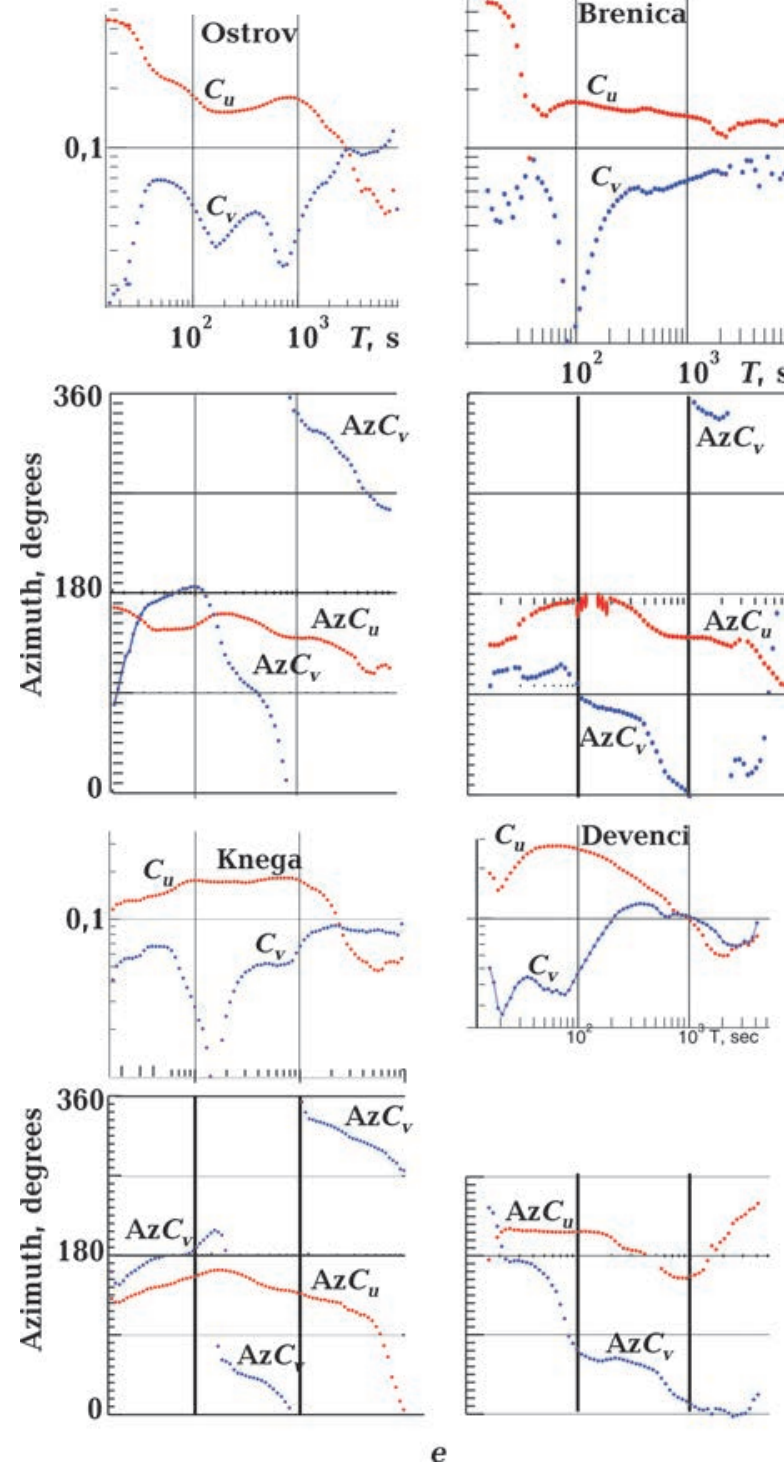

Fig. 6, e.

north to south. The ratio of $C_{u} / C_{v}$ changes in the same direction - from $0.2 / 0.01$ in Rzg to 0.2/0.07 in Mdn. $\mathrm{Az}_{u}$ will change from $270^{\circ}$ in Rzg to $200^{\circ}$ at other points $C_{u}$ and $C_{v}$.

A similar ratio of $C_{u}$ and $C_{v}$ is observed in the range of periods close to $1000 \mathrm{~s}$. The maximum value of $C_{u}$ in $B_{z v}$ reaches 0.4 . At other points of the profile, the value of $C_{u}$ is less than 0.2. For the first anomalous section of the periods, the $\mathrm{Az} C_{u}$ at the points south of the Rzg is close to $180^{\circ}$. In the second interval of the periods $\mathrm{Az} C_{u}$ is $110-130^{\circ}$. Such values of the $\mathrm{Az} C_{u}$ may indicate a change in the strike of the conductivity anomalies at different depths.
On prIIm (Fig. 6, b) in Btn, anomalous behavior of the parameters of the induction vector is observed at periods of $600-1000 \mathrm{~s}$ - the ratio of $C_{u} / C_{v}=0.12 / 0.04, \mathrm{AzC}_{u} 130^{\circ}$. In $\mathrm{Hrd}$ in the ranges of periods of $100-200 \mathrm{~s}$ and $600-800 \mathrm{~s}$, the ratio of $C_{u} / C_{v}$ is $0.24 / 0.06$ $\left(\mathrm{Az} C_{u}\right.$ varies slightly from $160^{\circ}$ to $140^{\circ}$ ). An anomalous ratio of $C_{u} / C_{v}$ is observed at Frn and Dvn in the range of periods of $50-60 \mathrm{~s}$ (0.24/0.05 and 0.4/0.1, respectively). $\mathrm{Az} C_{u}$ is $200^{\circ}$. At periods greater than $100 \mathrm{~s}$, no clear anomalousness of the parameters of the induction vector is observed.

On the prIIIm (Fig. 6, c) in Mtl, Gls, Lpn in the range of periods $100-1000 \mathrm{~s}$, the ratio of $C_{u}$ and $C_{v}$ corresponds to a two-dimensional conductivity anomaly - the maximum $C_{u}$ corresponds to a minimum $C_{v}\left(C_{u} / C_{v}\right.$ varying from 0.24/0.01 in Mtl to 0.21/0.06 in Lpn. $\mathrm{Az} C_{u}$ varies slightly from $140^{\circ}$ to $160^{\circ}$. At Brv anomalous behavior of the parameters of the induction vector is observed at periods of $60-160 \mathrm{~s}$ — the ratio of $C_{u} / C_{v}=0.3 / 0.08, \mathrm{Az}_{u} 170^{\circ}$.

On the BGr, BSl and Gbr prIYm (Fig. 6, d) in the range of periods about $60 \mathrm{~s}$ the ratio of $C_{u}$ and $C_{v}$ corresponds to a two-dimensional conductivity anomaly - most clearly at the Gbr. The maximum values of $C_{u}$ exceed the level of $0.3-0.4$, and the values of $C_{v}$ are $0.01-0.03$. The $\mathrm{Az} C_{u}$, in the range of periods close to $60 \mathrm{~s}$, increases from $160^{\circ}$ in BGr to $190^{\circ}$ in BSl and Gbr, whereas $\mathrm{Az}_{V}$ is $40^{\circ}$ in the Gbr.

At all points prYm (Fig. 6, e) in the interval of periods $100-200 \mathrm{~s}$, the ratio of $C_{u}$ and $C_{v}$ corresponds to a two-dimensional conductivity anomaly. The anomaly is most clearly manifested in Kng and Brn, where, at maximum $C_{u}$ values of $0.2, C_{u}$ values are less than 0.01. Az $C_{u}$ in Kng and Brn is $170^{\circ}$, and in Ost and Dvn $-160^{\circ}$ and $140^{\circ}$.

Parameters of sedimentary rocks are important for building geoelectric models of the Earth's crust and mantle. Sediments in Bulgaria are distributed unevenly [Iossifov et al., 1994]. The structure of the Moesian plate on the territory of Bulgaria is mainly determined by the two largest tectonic structures, the Lomskaya depression and the NorthBulgarian uplift. Within Moesian plate several structural complexes are identified. Nisa 
Upper Paleozoic clastic section is presented by carboniferous or red deposits that overlap clastic-carbonate sediments from the Triassic to the Cenozoic. Rocks of this composition usually have a resistivity of $10 \mathrm{ohm} \cdot \mathrm{m}$ and higher. The thickness of the Cenozoic sediments (composed by conglomerate, sand, clay, and loess) in the study region reaches $900 \mathrm{~m}$ [Zagorchev, 2009].

The usual resistivity of rocks of this composition is less than $1 \mathrm{ohm} \cdot \mathrm{m}$. For an objective assessment, MT research and logging data are required. Because MT methods have poor resolution in relation to the high rocks, pinpointing their resistivity is impossible. From the results of geoelectric studies on direct and alternating current and laboratory measurements it is known that the resistivity of the rocks forming the crystalline basement is much larger than $1000 \mathrm{ohm} \cdot \mathrm{m}$. The most common characteristic of geoelectric parameters of sedimentary cover is the total value of the longitudinal conductivity $\left(S_{\mathrm{sd}}=N / \rho, N\right.$ thickness of the layer with resistivity $\rho$ ) as certain types of rocks, and the whole thickness of sediments. Based on geological data and logging data for Romania, a schematic map of $S_{\text {sd }}$ was constructed [Scientific ..., 2013]. On the territory of Romania, in the area adjacent to the study area from the north, $S_{\text {sd }}$ reaches 1000 S. According to rough estimates (based on data on the thickness of sediments and their $\rho$ ) surface sediments overlying crystalline basement rocks on the territory of the Balkanides have a $S_{\text {sd }}$ of no more than $10-20 \mathrm{~S}$.

Taking into account the above, it can be assumed that the behavior of the real part of the induction vector $\left(C_{u}\right)$ will correspond to the distribution of precipitation of the total value of the longitudinal conductivity $\left(S_{\mathrm{sd}}\right)$. At the same time, it is possible to analyze the influence of the geoelectric parameters of the Earth's crust in zones of increased seismicity on the behavior of induction vectors. The performed analysis is based on the maps of induction vectors (Fig. 7) constructed for the periods in which the anomalous behavior of $C_{u}$ and $C_{v}$ is noted.

At the shortest ( $T$ about $20 \mathrm{~s}$ ) and longest periods ( $T$ range from 600 to $1000 \mathrm{~s}$ ), the $C_{u}$ directions completely coincide and indicate the presence of anomalous conductivity of the quasi-longitudinal strike to the west of the study area. This behavior of the $C_{u}$ vector is in good agreement with power isohypsum strike of the Cenozoic deposits. At intermediate periods of $50-200 \mathrm{~s}$, the behavior of $C_{u}$ is more complex. To the south of the rzg-kng line, the direction of the $C_{u}$ differs from the previous ones by almost 90 degrees.

Magnetotelluric sounding (MTS). Conditioned registration of electrical components was performed at 4 points (Btn, Frn, Brv, Brn). As a result of processing the MT field records, impedance estimates were obtained in the range of periods from 20 to $6400-8100 \mathrm{~s}$. As a result of the interaction of geoelectric inhomogeneities with the MT field, induction and galvanic effects arise, which are reflected in different ways by the magnetic and electrical components of the field. Galvanic distortion of the MT field leads to a static displacement of the MTS amplitude curves. To eliminate this effect, the MTS curves need to be normalized, which currently consists of restoring the normal position of the low-frequency branches reflecting the electrical conductivity of the lower parts of the tectonosphere. It is assumed that at depths over $400 \mathrm{~km}$, the horizontal changes in electrical conductivity are small and the MTS curves obtained in different regions should merge at periods exceeding 3 hours. In practice, usually, the normalization of the MTS curves consists of the displacement of the low-frequency parts of the MTS amplitude curves along the vertical axis to coincide with the $\rho$ curve corresponding to the regional geoelectric structure of the study region (if the MTS phase curves agree with the reference curve). For the study area, the results of magnetovariational sounding (MVS) obtained from geomagnetic data at the PAG observatory (for 1988-2015) were taken as the reference sounding curve [Srebrov et al., 2013; Ladanivskyy et al., 2019].

There are different approaches to the interpretation of MT curves. We have chosen a technique based on the interpretation of MTS curves in the main directions [Gordienko et al., 2005]. The dependence of the impedance 
Longitude [E], degrees
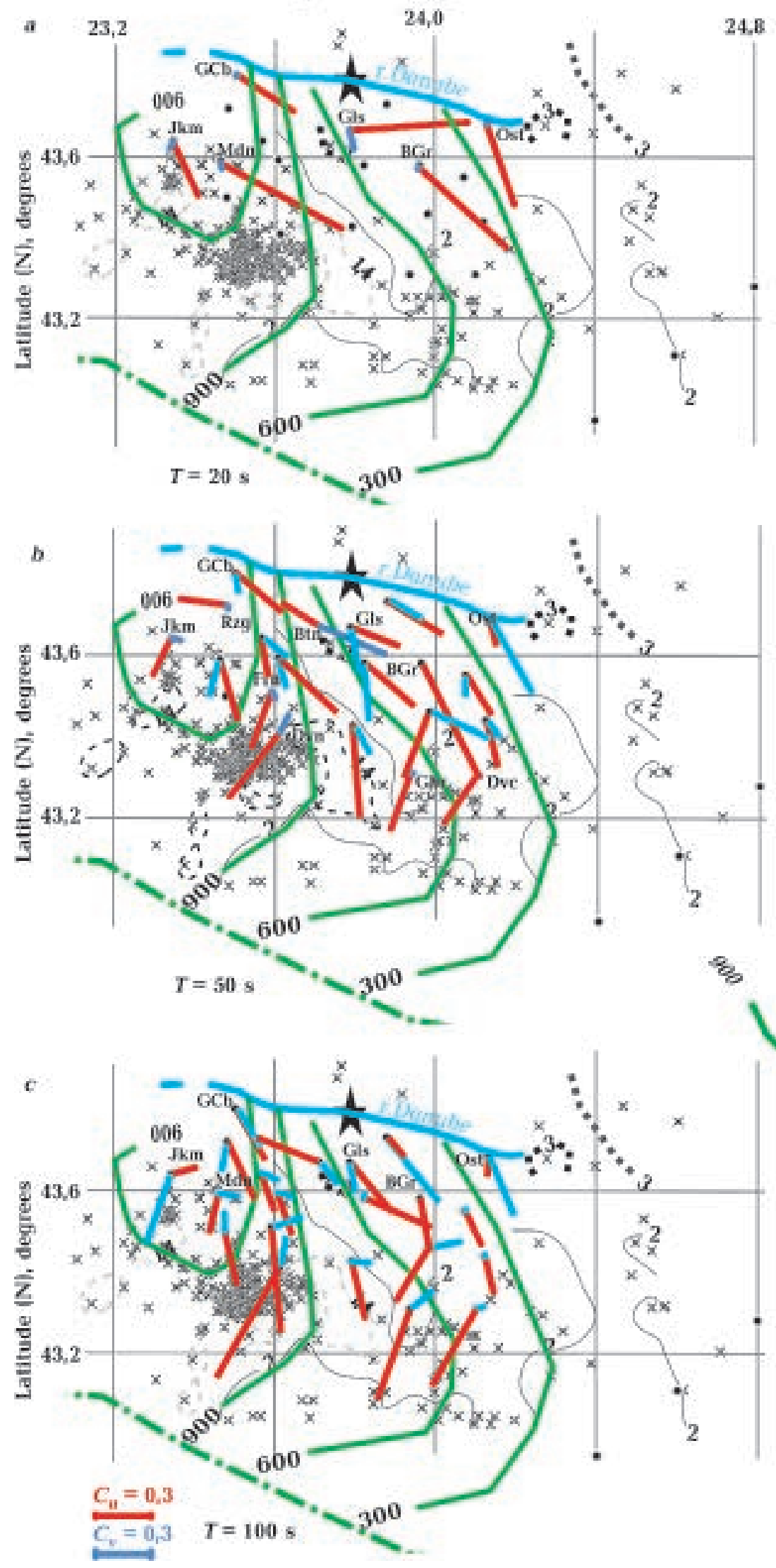


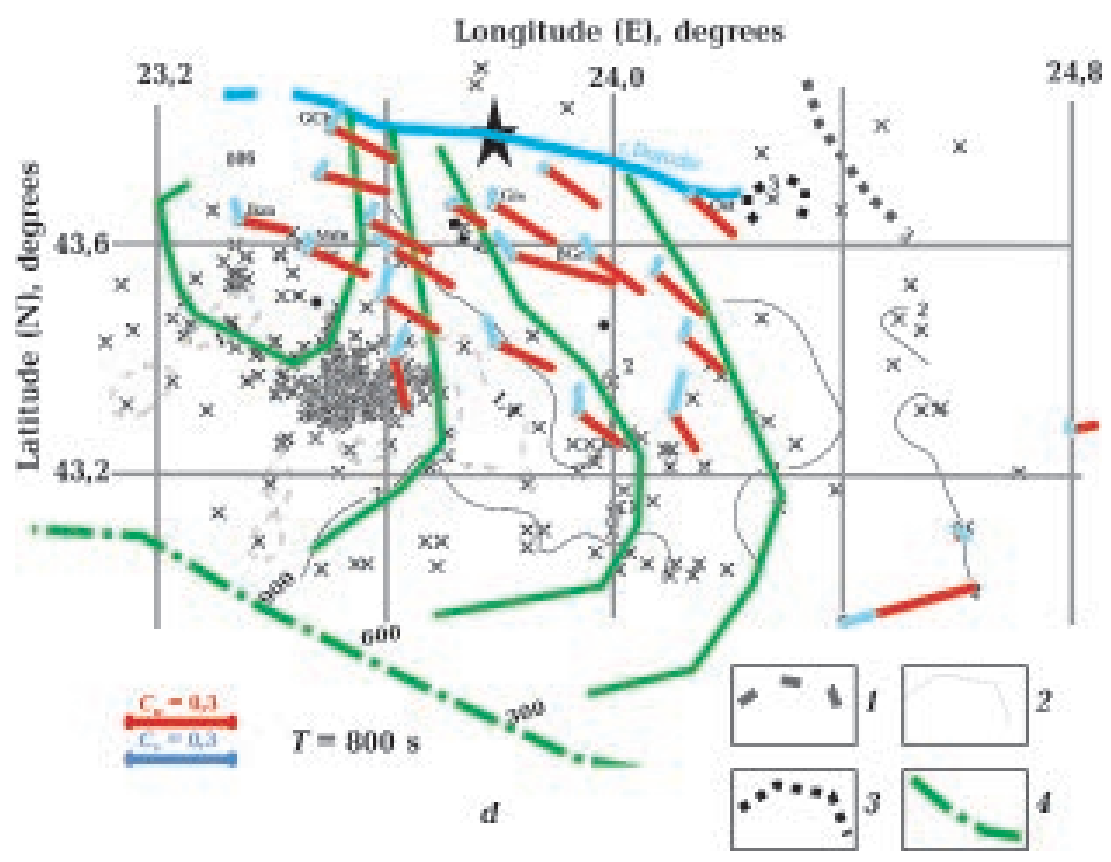

$\leftarrow$ Fig. 7. Distribution of induction vectors $\left(C_{u}-\right.$ red, $C_{v}-$ blue $)$ in the area of anomalous behavior of parameters in the region at the period of $20(a)$, $50(b), 100(c)$ and $800 \mathrm{~s}(d): 1-3$ - isolines of values of equal magnitudes $(1-1.4 ; 2-2 ; 3-3), 4$ - the boundary of the Moesian plate. Crosses - epicenters of earthquakes. Isolines of the thickness of Cenozoic sediments (green).

on the orientation of the measuring lines can be presented in the form of polar diagrams. According to the polar diagrams modules of the main and additional impedance, directions are found in which the value of the main impedance is many times higher than the additional one. These directions are called the main ones. In a two-dimensional model of anomalous conductivity, the polar diagram of the main impedances has the form of an elongated oval or figure eight, the major axis of which is oriented in the longitudinal direction and the small one in the transverse direction. With this approach, the data obtained are most adequate to the theoretical concepts of the theory of magnetotelluric sounding.

To select the MTS interpretation curve, the impedance parameterization was performed, which included the determination of the Skew parameter and azimuth to off-diagonal impedances of the impedance matrix (Fig. 8). The azimuth to main directions of the impedance matrix estimated from polar diagrams. The azimuth to main directions of the impedance matrix (corresponding to the maximum values of the impedances) correlate well with the azimuths in which there is a minimum of additional impedances of the polar diagrams. The azimuth to main directions is located within $100-130^{\circ}$ in the Frn, Brv, Brn and Btn about $40^{\circ}$. For most periods, the ratio of the polar diagrams of the main (in the form of a figure of eight) and additional impedances (in the four-petal form). The most reliable result of MTS interpretation is obtained in the main directions of the impedance matrix, where the ratio of the main and additional impedances assumes the highest values. At all points, the ratio of the main and additional impedances varies from $4-5$ to $8-9$. This kind of polar diagrams indicates the proximity of the geoelectric situation in the vicinity of the observation points a two-dimensional. Comparison of these azimuths with the azimuths of real 

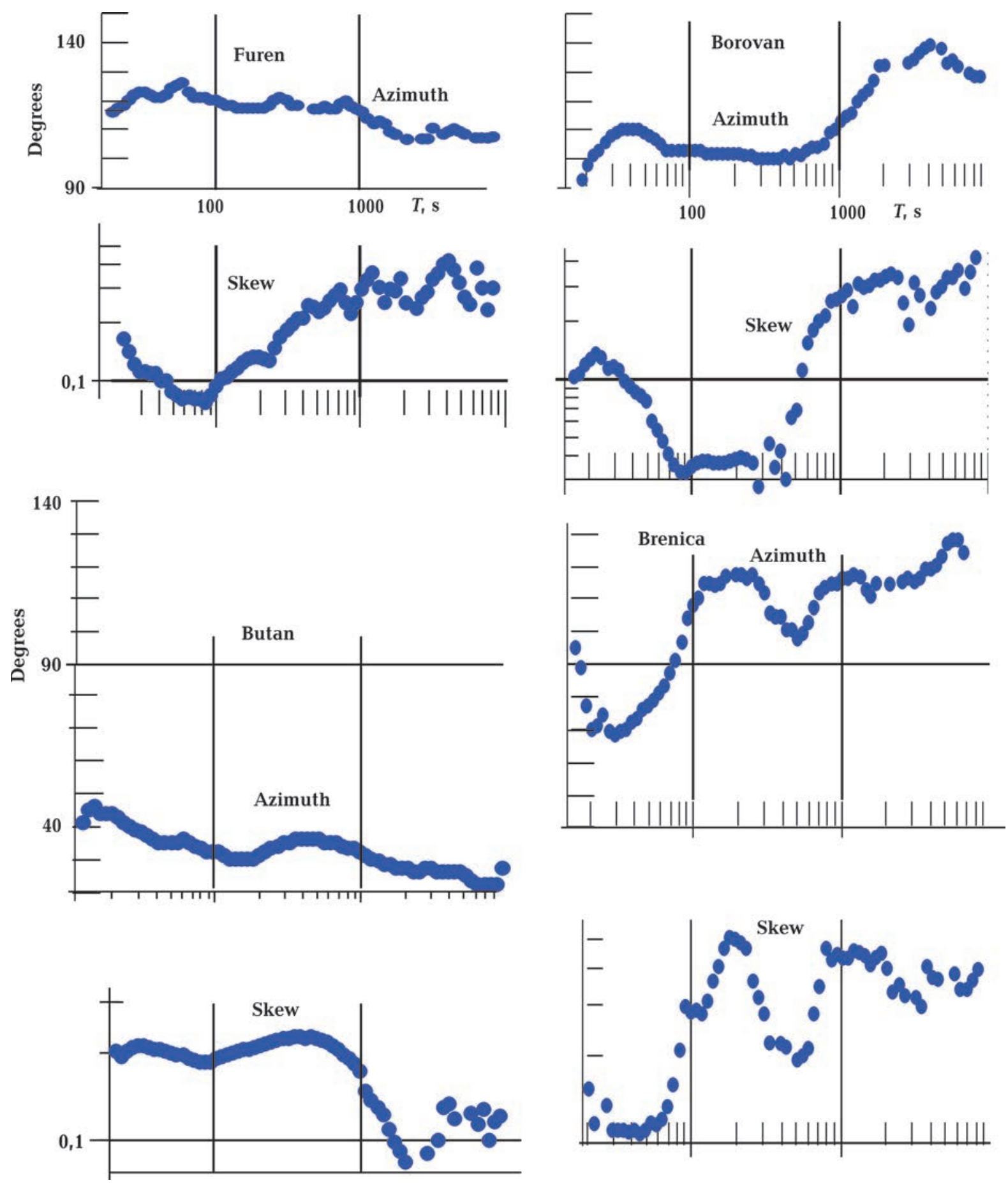

Fig. 8. Impedance matrix parameters: Skew and Azimuth to main direction.

induction arrows at the maximum frequency response shows that for Frn, Brv, Brn, the azimuths are close (i. e., the maximum MT curves correspond to the TM mode), and in Btn they are almost perpendicular (i. e., the maximum MT curves correspond to the TE mode).
The skew parameter is a measure of the asymmetry of the environment. If the medium is two-dimensional or axisymmetric, Skew $=0$. In practice, it is believed that for skew values $<0.3$, it can be assumed that the medium is close to two-dimensional. The values of the 
Skew are the largest in the Brn. In most periods, the value of skew exceeds 0.3 , while in other sites, this value is generally less than 0.3 (see Fig. 8). The recorded behavior of these parameters may indicate either the influence of powerful sources of interference on the components of the electric field, or a strong geoelectrical inhomogeneity in the vicinity of the Brc.
As a result of processing, it was possible to obtain the values of impedances and their phases in the range of periods from 16 to 8000 s. Fig. 8 shows the amplitude and phase MTS curves in the main directions of the impedance matrix used for interpretation.

1D inversion of MT curves. At the first stage, the selection of the parameters of the geoelectric section was based on a one-di-
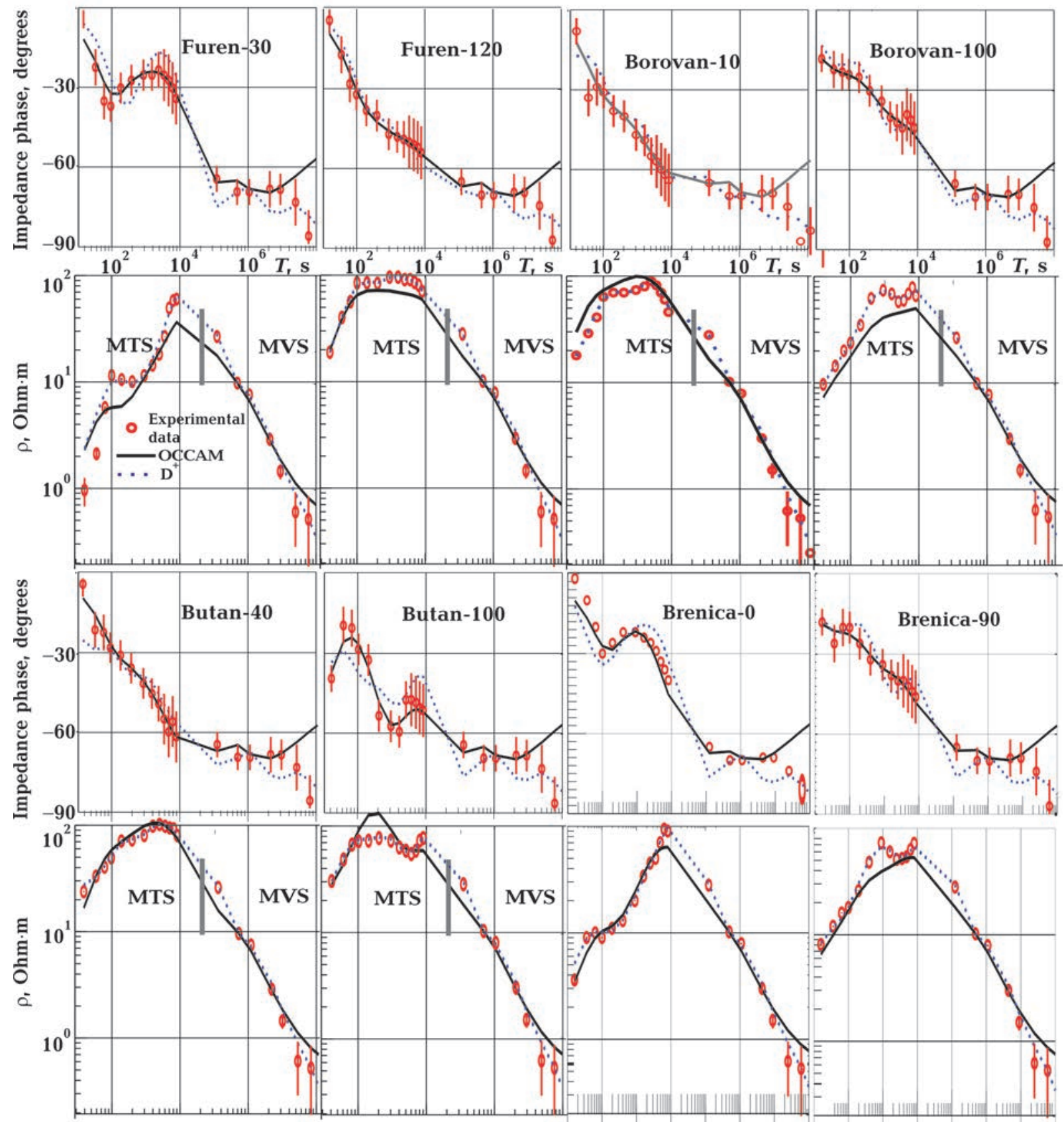

Fig. 9. Coincidence of experimental curves (circles) with model responses (continuous lines). 
mensional (1D) inversion of the interpretation curve. The well known $\mathrm{D}^{+}$[Parker, Whaler, 1981] and OCCAM [Constable et al., 1987] 1D inversion algorithm is usually used for calculation of the resistivity distribution models for each measurement site. The first method can be used to estimate the value of the total longitudinal conductance of the conductors isolated in the section, according to the data in the entire observed range of periods simultaneously. The second consists in the selection of a finite number of layers that are smoothly varying in conductivity and approximate the experimental data. OCCAM inversion is more sensitive to impedance phase values, while $\mathrm{D}^{+}$ inversion is more sensitive to $\rho$ values.

The results of $1 \mathrm{D}$ inversion by the two indi- cated methods are shown in Fig. 9. The MTS curves in the period band from few seconds up to $10^{4}$ s were connected with the MVS curve at the PAG geomagnetic observatory from $2 \cdot 10^{4} \mathrm{~s}$ to $2 \cdot 10^{7} \mathrm{~s}$ for the $1 \mathrm{D}$ inversion. Since the MVS curve not influenced by galvanic effects in the conductive medium MTS apparent resistivity curves were shifted to fit with MVS ones by levels before their joint 1D inversion. As can be seen from the Fig. 9, in general, the agreement between the calculated and experimental data is good. Indeed, after the reduction of the amplitude interpretation curve to agree with the MVS data, the model both inversions fit well to the generalized experimental sounding curves.

The geoelectric parameters of the layer
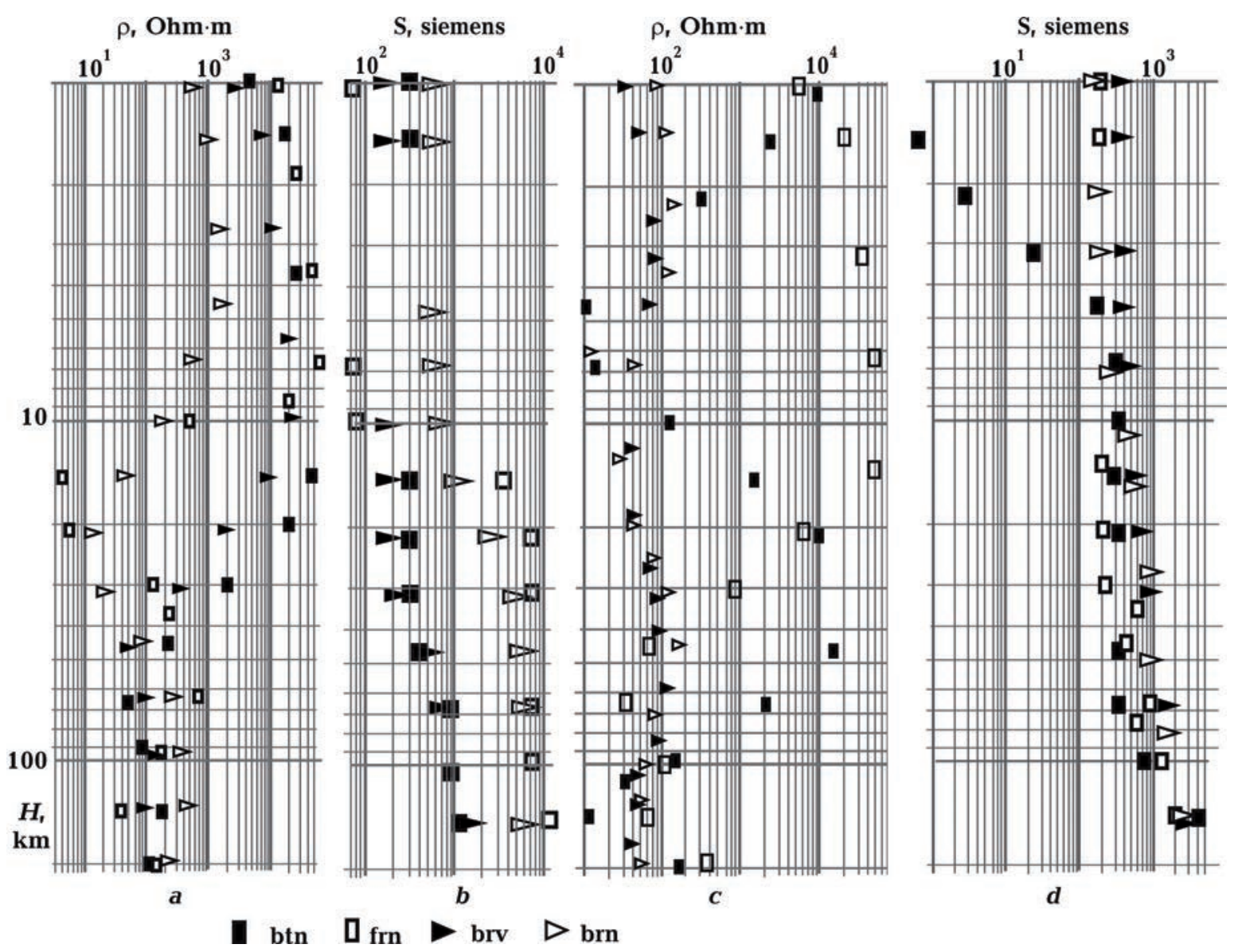

Fig. 10. Geoelectric resistivity sections ( $a$ ) and integral longitudinal conductivity $(b)$ for quasi-meridional (Az $0-30^{\circ}$ ) MTS curves. Geoelectric sections of resistances (c) and integral longitudinal conductivity (d) for quasi-latitude (Az 90-120 $)$ MTS curves. 
corresponding to sedimentary rocks can be estimated only from the values of $S$ down to a depth of about $1 \mathrm{~km}$ (which is due to the values of the initial periods of the MTS curves). These values are $150-400 \mathrm{~S}$ at different points and allow us to assume the value of precipitation $\rho$ less than $10 \mathrm{ohm} \cdot \mathrm{m}$ (which is many times less than the values of $\rho$ of the underlying rocks).

On the geoelectric sections (Fig. 10, $a, c$ ), obtained as a result of $1 \mathrm{D}$ inversions, anomalous layers (conductors) are identified, $\rho$ of which is much smaller than the layers lying above and below.

Concluding Remarks. The analysis showed that geoelectric data contribute to the study of the structure of the Earth's interior in the region of the Kozloduy NPP. The preliminary result is that in the Earth's crust of the region, well-conducting objects have been identified, which apparently impede the propagation of seismic waves from nearby earthquakes. For a more substantiated conclusion, additional observations are required in order to obtain magnetotelluric soundings, on the basis of which the propagation zone of an object (objects) with anomalously low resistivity can be delineated.

Against the background of rocks with a resistivity of many hundreds of ohm · $\mathrm{m}$, a conductive object in the area of Prn, Brv and Brn

\section{References}

Akasofu, S.-I., \& Chapman, S. (1973). Solar-terrestrial physics. Quarterly Journal of the Royal Meteorological Society, 99(422), 793-845. https://doi.org/10.1002/qj.49709942230.

Berdichevsky, M.N., \& Dmitriev, V.I. (2008). Models and Methods of Magnetotellurics. Springer, $563 \mathrm{p}$.

Constable, S.C., Parker, R.L., \& Constable, C.G. (1987). Occam's inversion: a practical algorithm for the inversion of electromagnetic data. Geophysics, 52(3), 289-300. https://doi. org/10.1190/1.1442303.

Dobrodnyak, L., Logvinov, I., Nakalov, E., Rakh- has the resistivity of about $10 \mathrm{ohm} \cdot \mathrm{m}$, the depth of the center of the object is $15-20 \mathrm{~km}$. According to the longitudinal (quasi-meridional) curves, the $S$ values of the object $(2000-4000$ S are almost an order of magnitude higher than the $S$ values of the overlying rocks.

Studies have shown that the anomalous high conductivity of the subsoil in the Kozloduy region is located to the west of the station and is not covered by the MT observation area. Conductive objects (the roof of which is located at depths less than $10 \mathrm{~km}$ ) found in the southern part of the study area can prevent the spread of seismicity manifestations towards the KNPP.

Acknowledgement. This work was carried out as part of the implementation a scientific project «Research on Partial Differential Equations and their applications in Modelling of non-linear processes", funded by Bulgarian National Science Fund, contract KP-06N42/2 and partially supported by scientific project 0117 U000117 «Deep processes in the crust and upper mantle of Ukraine and formation of mineral deposits» funded by National Academy of Sciences of Ukraine. We extend thanks to Dr S. Kovachikova (Institute of Geophysics of the Academy of Sciences of the Czech Republic) for reading the manuscript and making a number of suggestions.

lin, L. , \& Timoshin, S. (2014). Application of magneto-telluric stations (Geomag-02) in geoelectric studies on the territory of Bulgaria. Seminar proceedings, $16-20$ December, 2013 INRNE-BAS, Sofia, Bulgaria (Vol. 3, pp. 148-151).

Gordienko, V.V., Gordienko, I.V., Zavgorodnyaya, O.V., Kovachikova, S., Logvinov, I.M., Tarasov, V.N., \& Usenko, O.V. (2005). Ukrainian Shield (Geophysics, Deep Processes). Kiev: Korvin Press, 210 p. (in Russian).

Iossifov, D.S., Zagorchev, I.S., \& Bojan, I.I. (1994). Balkans. In A.V. Chekunov (Ed.), Lithosphere 
of Central and Eastern Europe: Young platform and Alpine fold belt (pp. 161-190). Kiev: Naukova Dumka (in Russian).

Ladanivskyy, B.T. (2003). Algorithm for processing MTZ data. Fifth geophysical readings named after V.V. Fedynsky February 27-March 01, 2003. Abstracts of reports (pp. 134-135) (in Russian).

Ladanivskyy, B., Logvinov, I., \& Tarasov, V. (2019). Earth mantle conductivity beneath the Ukrainian territory. Studia Geophysica et Geodaetica, 63, 290-303. https://doi.org/10.1007/ s11200-018-0347-4.

Logvinov, I., Gordienko, I., \& Tarasov, V. (2020). The results of geothermal and geoelectric studies in the regions of Rivne, Khmelnitsky and Uzhno-Ukrainsk NPPs. Geofizicheskiy Zhurnal, 42(6), 164-175. https://doi.org/10.24028/ gzh.0203-3100.v42i6.2020.222291 (in Russian).

Parker, R.L., \& Whaler, K.A. (1981). Numerical method for establishing solution to the inverse problem of electromagnetic induction. $J_{O}$ urnal of Geophysical Research: Solid Earth, 86(B10), 9574-9584. https://doi.org/10.1029/ JB086iB10p09574.

Schmucker, U. (1970). Anomalies of geomagnetic variations in the southwestern United States. Bulletin of the Seripps Institute of Oceanography University of California, 13, 13-32.

Scientific Report the project «The geomagnetic field under the heliospheric forcing. Determination of the internalstructure of the Earth and evaluation of the geophysical hazard produced by solar eruptive phenomena». Program IDEI, Contract 93/5.10.2011, Stage I-III. Institute of Geodynamics Romanian Academy. 2013. 28 p. Retrieved from http://www.geodin.ro/IDEI2011 /engl/index.html.

Srebrov, B., Ladanivskyy, B., \& Logvinov, I. (2013). Application of space generated geomagnetic variations for obtaining geoelectrical characteristics at Panagyurishte geomagnetic observatory region. Comptes rendus de l'Acade'mie Bulgare des Sciences, 66 (6), 857864.

Srebrov, B., Logvinov, I., Rakhlin, L., \& Kovacikova, S. (2018). Results of the magnetotelluric investigations at geophysical observatories in Bulgaria. Geophysical Journal International, 215(1), 1656-180. https://doi.org/10.1093/ gji/ggy268.

Turbitt, C., Matzka, J., Rasson, J., St-Louis, B., \& Stewart, D. (2012). An instrument performance and data quality standard for INTERMAGNET one-second data exchange. In XVth IAGA Workshop on Geomagnetic Observatory Instruments and Data Processing, Cadiz, Spain, 4-14 June 2012 (pp. 186-188).

Varentsov, I.M. (2007). Joint robust inversion of MT and MV data. In Electromagnetic sounding of the Earth's interior (Methods in geochemis try and geophysics) (pp. 189-222). Elsevier.

Zagorchev, I. (2009). Geomorfological formation of Bulgaria. Principles and state of the art. Comptes rendus de l'Acade'mie bulgare des Sciences, 62(8), 981-992. 


\title{
Геоелектричні дослідження в районі Козлодуйскої атомної станції, Болгарія
}

\author{
I. Аогвінов ${ }^{1}$, Г. Бояджиев ${ }^{2}$, Б. Сребров $^{2}$, А. Рахлін $^{3}$, Г. Аогвінова ${ }^{1}$, \\ С. Тімошін ${ }^{3}, 2021$
}

\author{
${ }^{1}$ Інститут геофізики ім. С.І. Субботіна НАН України, Київ, Україна \\ ${ }^{2}$ Інститут математики та інформатики, АН Болгарії, Софія, Болгарія \\ ${ }^{3}$ Аослідницький центр GEOMAGNET, Аьвів, Україна
}

\begin{abstract}
Виконано геоелектричні дослідження з використанням варіацій магнітотелуричного (МТ) поля в районі Козлодуйської атомної електростанції (KAEC) в рамках наукового проєкту «Research on Partial Differential Equations and their applications in Modelling of non-linear processes», за фінансування Болгарським національним научним фондом, контракт KP-06N42/2. У статті наведено результати визначення інтерпретаційних параметрів МТ поля. KAEC розташована на правому березі Аунаю в безпосередній близькості від річки. Цей факт у сукупності з розташуванням електрифікованих залізниць визначив унікальність мережі розташування пунктів спостережень за варіаціями МТ поля. На підставі аналізу каталогів землетрусів Болгарії та міжнародних баз сейсмічності побудовано карту сейсмічності регіону АЕС. За останні 50 років зареєстровано близько 750 землетрусів, в основному на південь від KAEC на відстані 40-80 км від неї. На ділянках вимірювань використовували Аві магнітотелуричні станції GEOMAG-02. Варіації МТ поля спостерігали в 21 точці, які розташовані на території зі сторонами приблизно 30-35 км зі сходу на захід і 40-50 км з півночі на південь. Аля всіх точок спостереження визначали тільки параметри передавальних функції вертикального магнітного поля (ВМПФ) у вигляді дійсної $\left(C_{u}\right)$ та уявної $\left(C_{v}\right)$ частин вектора індукції. Значення ВМПФ визначені для періодів $(T)$ від 10-20 до 4900-10 800 с. У більшості точок вдалось оцінити значення $C_{u}, C_{v}$ з похибкою $0,02-0,04$, азимути $C_{u}$ та $C_{v}$ становлять $3-5^{\circ}$. Аналіз показав наявність аномальної поведінки $C_{u}, C_{v}$ в різних інтервалах періодів у деяких точках. На найкоротшому ( $T$ близько 20 с) і найдовшому періодах (діапазон $T$ від 600 до 1000 с) напрямки $C_{u}$ повністю збігаються, що засвідчує наявність аномальної провідності квазімеридіонального простягання на захід від району досліджень. Така поведінка вектора $C_{u}$ добре узгоджується з ізогіпсами простягання кайнозойських відкладів ломської депресії. На проміжних періодах 50-200 с поведінка $C_{u}$ є складнішою. 3 наближенням до зони підвищеної сейсмічності напрямок $C_{u}$ у пунктах, розташованих на північ від цієї зони, різниться майже на $90^{\circ}$. На геоелектричних розрізах, отриманих у результаті одновимірних інверсій кривих MTS у чотирьох пунктах, розташованих у південній частині регіону, спостерігаються об'єкти зменшеного опору ( $\rho$ близько 10 Ом · м, глибина центра об'єкта 15-20 км). Можна припустити, що добре провідні об'єкти в земній корі регіону, можливо, перешкоджають поширенню сейсмічних хвиль від довколишніх землетрусів на північ у бік КАЕС.
\end{abstract}

Ключові слова: електропровідність, сейсмічність, АЕС Болгарії. 


\title{
Геоэлектрические исследования в районе Козлодуйской атомной станции, Болгария
}

\author{
И. Аогвинов ${ }^{1}$, Г. Бояджиев ${ }^{2}$, Б. Сребров $^{2}$, А. Рахлин ${ }^{3}$, \\ А. Аогвинова ${ }^{1}$, С. Тимошин ${ }^{3}, 2021$ \\ ${ }^{1}$ Институт геофизики им. С.И. Субботина НАН Украины, \\ Киев, Украина \\ ${ }^{2}$ Институт математики и информатики АН Болгарии, \\ София, Болгария \\ ${ }^{3}$ Исследовательский центр GEOMAGNET, львов, Украина
}

Проведены геоэлектрические исследования с использованием вариаций магнитотеллурического (МТ) поля в районе Козлодуйской атомной электростанции (KAЭС) в рамках научного проекта «Research on Partial Differential Equations and their applications in Modelling of non-linear processes», при финансировании Болгарским национальным научным фондом, контракт KP-06N42/2. В статье представлены результаты определения интерпретационных параметров МТ поля. КАЭС расположена на правом берегу Ауная в непосредственной близости от реки. Этот факт в совокупности с расположением электрифицированных железных дорог определил уникальность сети расположения пунктов наблюдений вариаций МТ поля. На основе анализа каталогов землетрясений Болгарии и международных баз Аанных построена карта сейсмичности территорий АЭС. За последние 50 лет зарегистрировано около 750 землетрясений, в основном к югу от КАЭС на расстоянии 40-80 км от нее. Аля измерений использовались две магнитотеллурические станции GEOMAG-02. Наблюдения вариаций МТ поля выполнены в 21 пункте, которые расположены на территории со сторонами примерно 30-35 км с востока на запад и 40-50 км с севера на юг. Аля всех пунктов наблюдений определялись только параметры передаточных функций вертикального магнитного поля (ВМПФ) в виде действительной $\left(C_{u}\right)$ и мнимой $\left(C_{v}\right)$ частей вектора индукции. Значения ВМПФ определены для периодов от 10-20 до 4900-10 800 с. В большинстве точек удалось оценить значения $C_{u}, C_{v}$ с погрешностью $0,02-0,04$, азимуты $C_{u}$ и $C_{v}$ равны $3-5^{\circ}$. Анализ показал наличие аномального поведения $C_{u}, C_{v}$ в разных интервалах периодов в некоторых пунктах. В самом коротком интервале (T около 20 с) при наиболее длинных периодах ( $T$ - от 600 до 1000 с) направления $C_{u}$ полностью совпадают, что свидетельствует о наличии аномальной проводимости квазимеридионального простирания западнее района исследований. Такое поведение вектора $C_{u}$ хорошо согласуется с изогипсами простирания кайнозойских отложений Ломской депрессии. На промежуточных периодах 50-200 с поведение $C_{u}$ более сложное. При приближении к зоне повышенной сейсмичности направление вектора $C_{u}$, в пунктах, расположенных севернее этой зоны, отличается почти на $90^{\circ}$. На геоэлектрических разрезах, полученных в результате одномерной инверсии кривых MTS в четырех пунктах, расположенных в южной части региона исследований, наблюдаются объекты пониженного сопротивления ( $\rho$ около 10 Ом · м, глубина центра объекта 15-20 км). Можно предположить, что хорошо проводящие объекты в земной коре региона, по-видимому, препятствуют распространению сейсмических волн от близлежащих землетрясений на север в сторону КАЭС.

Ключевые слова: электропроводность, сейсмичность, АЭС Болгарии. 